International Journal of Public Finance
E-ISSN: $2548-0499 \quad$ DOI: $10.30927 /$ ijpf. 356692
Vol./Cilt: 2 | Issue/Sayı: 2 | (2017), pp. $245-263$
journal homepage: http://dergipark.gov.tr/ijpf

\title{
Bağımlılık Teorisi Perspektifinden DTÖ Kapsamındaki Korumacılık Politikası Araçlarının Kullanımı
}

\author{
Using of Protectionism Policy Tools in the context of WTO from the \\ Perspective of Dependency Theory
}

\begin{tabular}{|c|c|}
\hline ARTICLE INFO & A B STRACT \\
\hline $\begin{array}{l}\text { Received: } 21.11 .2017 \\
\text { Received in revised } \\
\text { form: } 05.01 .2018 \\
\text { Accepted: } 07.01 .2018 \\
\text { Available online: } \\
\text { 08.01.2018 }\end{array}$ & $\begin{array}{l}\text { Since the 1980s, when neoliberal policies have been intensively } \\
\text { implemented, the distribution of income between developed and less } \\
\text { developed countries in the world has begun to increase inequality. There } \\
\text { are discourses that the neoliberal view suggests that today's wealthy } \\
\text { countries are successful with free market economics, so that all countries in } \\
\text { the world must move to a free market economy system and that neoliberal }\end{array}$ \\
\hline $\begin{array}{l}\text { JEL classification: } \\
\text { E13, O10, F13 }\end{array}$ & $\begin{array}{l}\text { policies are the only way for development. According to the neoliberal } \\
\text { policy which advocates the state neutrality in the economy, the role of the }\end{array}$ \\
\hline $\begin{array}{l}\text { Keywords: } \\
\text { Neoliberalism, Theory } \\
\text { of Dependency, World } \\
\text { Trade Organization }\end{array}$ & $\begin{array}{l}\text { state in the economy should be reduced. As a result, weakening the } \\
\text { effectiveness of government policy-setting and implementation in the } \\
\text { economy is intended. Thus, developed countries direct the underdeveloped } \\
\text { or developing countries in the direction of their own interests. The result of } \\
\text { these discourses, the theory of dependence which states that there is a } \\
\text { relationship between developed and underdeveloped countries based on } \\
\text { power and control, that underdevelopment of underdeveloped countries } \\
\text { should be sought in the development process of developed countries has } \\
\text { come out. The aim of the study is to assess the results of the use of defense } \\
\text { measures in the trade policy implemented under the World Trade } \\
\text { Organization (WTO), based on the assumptions of the dependency theory. } \\
\text { When the use of defense instruments in trade policy is examined, it appears } \\
\text { that these instruments have been effectively used by developed countries } \\
\text { that advocate and enforce the free market economy in the world. }\end{array}$ \\
\hline
\end{tabular}

1 Araş. Gör., Dumlupınar Üniversitesi, iïBF Uluslararası Ticaret ve Finans Bölümü, goksel.karas@dpu.edu.tr 


\section{MAKALE BILGISi}

Alındı: 21.11.2017

Gözden geçirilmiş alındı: 05.01.2018

Kabul: 07.01.2018

Yayın: 08.01.2018

\section{JEL Kodu:}

E13, 010, F13

Anahtar Kelimeler:

Neoliberalizm,

Bağımlılık Teorisi,

Dünya Ticaret Örgütü

\section{ÖZET}

Neoliberal politikaların yoğun bir şekilde uygulanmaya başladığı 1980’lerden itibaren dünyada gelişmiş ülkeler ile az gelişmiş ülkeler arasındaki gelir dağılımındaki eşitsizlik giderek artmaya başlamıştır. Neoliberal görüşün öne sürdügü günümüz zengin ülkelerinin serbest piyasa ekonomisi ile başarılı oldukları, bu nedenle dünyadaki tüm ülkelerin serbest piyasa ekonomisi sistemine geçmeleri gerektiği ve kalkınma için neoliberal politikaların tek yol olduğu gibi söylemleri bulunmaktadır. Devletin ekonomide tarafsız olmasını savunan neoliberal politikalara göre devletin ekonomideki rolü azaltılmalıdır. Bunun sonucunda devletin ekonomide politika belirleme ve uygulama etkinliğinin zayıflatılması amaçlanmaktadır. Böylelikle gelişmiş ülkeler, az gelişmiş veya gelişmekte olan ülkeleri kendi çıkarları doğrultusunda yönlendirmektedir. Bu söylemler sonucu gelişmiş ülkeler ile az gelişmiş ülkeler arasında güce ve kontrole dayanan bir ilişkinin bulunduğunu, az gelişmiş ülkelerin az gelişmişliğini gelişmiş ülkelerin gelişme sürecinde aranması gerektiğini ifade eden bağımlılık teorisi ortaya çıkmıştır. Buradan hareketle çalışmanın amacı, bağımlılık teorisinin varsayımlarından hareketle Dünya Ticaret Örgütü (DTÖ) kapsamında uygulanan ticaret politikası savunma araçlarının kullanım sonuçlarının değerlendirilmesi olarak belirlenmiştir. Ticaret politikası savunma araçlarının kullanımı incelendiğinde bu araçların, dünyada serbest piyasa ekonomisini savunan ve uygulanması konusunda dayatmalarda bulunan gelişmiş ülkeler tarafından etkin bir biçimde kullanıldığı görülmektedir.

\section{Giriş}

Adam Smith tarafından 1776 yılında yayınlanan "Ulusların Zenginliği" isimli eserde merkantilist politikalar eleştirilmekte ve serbest piyasa ekonomisinin önemine vurgu yapılmaktadır. A.Smith, merkantilizmin savunduğu ülkelerin zenginliklerinin kaynağının değerli maden stoku olduğu, piyasaya devlet müdahalesinin gerekli olduğu ve dış ticarette değerli madenlerin ülke sınırları içerisinde kalması için korumacı politikaların uygulanması gerektiği yönündeki düşüncelerine karşı çıkmıştır. A. Smith'e göre ülkelerin zenginliklerinin tek yolu serbest ticaret politikasıdır ve bu nedenle de dış ticareti kısıtlayıcı hiçbir politika uygulanmamalıdır (Schumacher, 2012: 54). Klasikler, merkantilist politikalar yoluyla serbest ticaretin kısıtlanması durumunda piyasaların daralacağı, ulusal refah ve ekonomik büyümenin düşeceği görüşünü savunmaktadırlar (Kalaycıoğlu, 1991: 14). Aynı zamanda merkantilizmin aksine piyasaya devlet müdahale etmemelidir. Çünkü piyasa daima tam istihdamdadır ve doğal dengededir. Bu denge görünmez el tarafından sağlanmaktadır. Bu bağlamda "bırakınız yapsınlar, bırakınız geçsinler" düşüncesiyle hareket eden klasikler ekonomide devlet müdahalesine karşı çıkmaktadırlar. Klasiklere göre, devlet jandarma devlet olarak görülmekte ve zorunlu fena olarak kabul edilmektedir (Tokatlıoglu \& Selen, 2017: 53). Devlet, serveti tüketen, ceza veren ve kaynakları verimsiz olarak kullanan bir yapı olarak kabul edilmektedir. Bu nedenle devlet sadece güvenlik, savunma, adalet ve diplomasi görevlerini üstlenmelidir. 
Bunun yanında devlet, piyasada oluşabilecek bir takım aksaklıkların varlığı durumunda özgürlüklerin ve fiyat mekanizmasının korunması amacıyla müdahalede bulunmalıdır (Öztürk, 2014: 27). Bu dönemden başlayarak Birinci Dünya Savaşına kadar dünyada serbest piyasa ekonomisi uygulanmıştır. Bu dönem, birinci küreselleşme dönemi olarak da adlandırılmaktadır. Ancak Birinci Dünya Savaşının ortaya çıkması ve ardından tüm dünyayı etkileyen 1929 Büyük Buhran nedeniyle serbest piyasa ekonomisi sorgulanmaya başlanmış ve ekonomide meydana gelen durgunluğun ancak devlet müdahalesi ile aşılabileceği görüşü yaygınlaşmaya başlamıştır. John Maynard Keynes krizin derinleşmesinde klasiklerin temel varsayımlarının etkili olduğunu ileri sürmektedir. John Maynard Keynes, 1936 yılında yayınladığı "İstihdam, Faiz ve Paranın Genel Teorisi" isimli eserinde, emek piyasasında tam rekabetin değil monopol koşulların geçerli olduğunu, ücretlerin aşağı yönünde yapışkan olduğunu, Say Kanununun geçerli olmadığını, tasarruf ve tüketimin faiz oranı tarafından değil gelir düzeyi tarafından belirlendiğini ve miktar teorisinin geçerli olmadığını iddia etmiştir. Keynes, ücretlerin aşağı yönlü yapışkan olduğu yönündeki iddiasıyla ekonominin kendiliğinden ve daima tam istihdama gelemeyeceği ancak devlet müdahalesi ile dengeye gelebileceğini vurgulamıştır (Tokatlıoğlu \& Selen, 2017: 59).

1913 yılından İkinci Dünya Savaşı sonuna kadar dünya genelinde korumacılık politikaları yaygın bir şekilde uygulanmış ve ekonomi devlet müdahalesi ile yönlendirilmiştir. İkinci Dünya Savaşını izleyen yıllarda uluslararası ticaretin serbestleştirilmesi anlamında yaşanan gelişmeler, çok uluslu şirketlerin (ÇUŞ) öneminin artması, Avrupa Ekonomik Topluluğu'nun (AET) oluşumu ve etkinliğinin artması gibi durumlar yaşansa da bu dönemde dünya genelinde bir küreselleşme olgusundan bahsedilemez. Bunun nedenleri, İkinci Dünya Savaşı sonrası siyasi bağımsızlıklarını kazanan az gelişmiş ülkelerin devlet önderliğinde içe dönük sanayileşme politikaları uygulaması ve sanayileşmiş ülkelerin de Soğuk Savaş sebebiyle bu duruma tepkisiz kalmaları ile az gelişmiş ülkelerin çoğunun yabancı yatırımlar yerine devletlerarası borçlanmayı tercih etmeleridir (Şenses, 2004: 2).

1973 yılına gelindiğinde petrol ihraç eden ülkeler gelirlerini artırmak amacıyla petrol fiyatlarını büyük oranda yükseltmişlerdir. Bunun sonucunda Petrol Krizi ortaya çıkmıştır. Petrol ihraç eden ülkelerin petrol fiyatlarını artırmaları sonucu artan gelirlerini gelişmiş ülkelerin finansal piyasaları aracılığı ile içe dönük sanayileşme politikası uygulayan ve finansman sıkıntısı çeken az gelişmiş ülkelere aktarmaya başlaması, bir süre sonra bu ülkelerin finansal piyasaların önemini anlamalarına yardımcı olmuştur (Şenses, 2004: 2). Bu durum aynı zamanda 1980'li yıllarda yoğun bir şekilde uygulanmaya başlanacak neoliberal politikaların altyapısını oluşturmuştur. 1980'li yıllardan itibaren dünya ekonomisinin kalkınması için İngiltere eski başbakanı Thatcher'ın "başka seçenek yok" (Chang \& Grabel, 2005: 11) sözü kapitalist sistem temelli neoliberal politikaların kaçınılmaz olduğu algısını güçlendirmiştir. Neoliberallere göre, kaynak kullanım etkinliği sadece serbest piyasa koşullarında sağlanabilecek ve bu nedenle devletin ekonomi yönetimindeki rolü sadece parasal tabanın kontrolü ve 
toplumsal olumsuzlukların düzeltilmesi ile sınırlı kalmalıdır (Selen, 2008: 100). Bu yaklaşımla devletin küresel sermaye, mal ve hizmet hareketleri önündeki kamusal regülasyonların en aza indirilmesi sağlanarak, tarihsel süreçte evrimleşen küreselleşmenin yeni bir aşamaya ulaşması sağlanmıştır. Yeni dönem neoliberal küreselleşme dönemi olarak ifade edilmektedir. Ancak, 2008 ekonomik kriziyle başlayan yeni süreçte ekonomi yönetiminde ulusal politikalara yeniden dönüş eğilimleri gözlenmektedir.

Neoliberal küreselleşme sürecinin hızlı bir şekilde ilerlemesi ve derinleşmesinde Amerika Birleşik Devletleri $(A B D)$ gibi gelişmiş ülkeler ile bu ülkelerin güdümünde oluşturulan Uluslararası Para Fonu (IMF), Dünya Bankası (DB) ve DTÖ gibi kuruluşların önemli etkileri olmuştur (Şenses, 2004: 3). Bu kuruluşlar neoliberal politikaların uluslararası düzeyde yerleşmesi ve dünya piyasalarının entegrasyonunun sağlanmasında etkili olmuştur. IMF, ödemeler dengesi açığına bağı istikrarsızlık yaşayan ülkelere stand-by anlaşmaları ile adeta dayatmada bulunurken, Dünya Bankası da kalkınma kredilerinin kullandırımasını neoliberal temelli yapısal uyum politikalarının izlemesi şartına bağlamıştır. DTÖ kurucu anlaşması ile de neoliberal politikalar dünya ekonomisinin yönetiminde önemli rol üstlenmiştir. Gelişmiş ülkelerin yönetiminde etkili olduğu bu üç kurum özellikle dış ticaretin serbestleştirilmesi ve neoliberal politikaların uygulanması hususunda az gelişmiş ülkelerin uluslararası sermayenin çıkarlarına sonuç verecek politikaların uygulanmasında etkili olmuşlardır.

Uluslararası sermayenin çıkarına uygun politika uygulamalarına imkan sağlayan DTÖ mekanizmaları ve işleyişleri bu çalışmanın ana çerçevesini oluşturmaktadır. Çünkü uluslararası ticaretin serbestleştirilmesi amacıyla ticaretin önündeki engellerin kaldırılması hedefi görüntüsü altında DTÖ, az gelişmiş ve gelişmekte olan ülkelerin dünya pazarındaki hareket alanlarını kısıtlayıcı bir takım mekanizmaları bünyesinde bulundurmaktadır.

Bazı ülkelerin diğer ülkelere oranla neden az geliştiklerine ilişkin soruya farklı yaklaşımlarla cevap aranmaktadır. Bağımlılık teorisi de bu soruya cevap aramış ve az gelişmişliğin nedenini gelişmiş ülkelerin gelişme süreci ile açıklamaya çalışmıştır. Bağımlılık teorisine göre gelişmiş ülkelerin izlediği politikalar az gelişmiş ülkelerin gelişimini engelleyen en önemli unsurdur. Bağımlılık teorisinin bu hipotezi DTÖ kapsamında oluşturulan ticaret politikası savunma araçları özelinde değerlendirilecektir.

\section{Bağımlılık Teorisi}

Bağımlılık teorisi, Latin Amerika'da geleneksel Marksist ve yapısalcı düşüncelerden etkilenerek ortaya çıkmıştır (Palma, 2008: 1). Geleneksel Marksist düşüncede Marx, kapitalizmi yayılmacı ve sömürgeci karakteri üzerinden tahlil 
etmektedir. Marksist yaklaşıma göre kapitalist ülkeler az gelişmiş ülkeleri kendilerine bağımlı kılacak politikaları uygulamaktan kaçınmamaktadır.

Arjantinli ekonomist Prebisch, hem akademik hem de uygulama boyutuyla sağladığı katkılarından dolayı, yapısalcı yaklaşımın öncüsü olarak gösterilebilir. Prebish, Birleşmiş Milletler'in Latin Amerika Ekonomik Komisyonu (ECLA) genel başkanlığı görevini yürüttüğü dönemde serbest ticaret teorileri üzerinde yoğunlaşmıştır. Prebish, uluslararası ticaretin klasik teorisi olan "dış ticaretten her ülkenin kazançlı çıkacağı" varsayımının şüphe uyandırdığını, dolayısıyla Latin Amerika ülkelerini bağımlıı̆̆a ittiğini vurgulamıştır (Ercan, 2003: 126). Latin Amerika ülkelerinin az gelişmişliğinin temel gerekçesi olarak kısa vadede mal fiyatlarındaki dalgalanmalar, uzun vadede ise bu ülkelerin görece fiyatlarının düşme eğiliminde olan hammadde ihracatına bağımlı olmaları olarak gösterilmektedir. Singer tarafından yapılan araştırmalar, dış ticaret hadlerinin Latin Amerika ülkelerinin aleyhine döndüğünü ortaya koymaktadır. Singer Prebisch analizi, dünya ticaret sistemine neoliberal temelli politikalarla katılımın birçok gelişmekte olan ülke için kayıpla sonuçlandığına dikkat çekmektedir (Sanchez, 2003: 37). Bu nedenle Prebish, dünya ekonomisinin merkez ve çevre ülkeleri arasındaki ilişki temelinde şekillendiğini ve bu ilişkinin geri kalmışlığın temel gerekçesini oluşturduğunu ve bundan dolayı az gelişmiş çevre ülkelerinin kalkınmalarını sağlamaları için ithal ikameci politikalara yönelmelerini önermektedir.

Yapısalcı yaklaşımın benimsediği merkez-çevre ilişkisi üzerinden gelişen "bağımlııı teorisi" bu ilişkiyi daha güçlü biçimde ele almıştır. Bu ekolün önde gelenleri Paul Baran, Celso Furtado, Osvaldo Sunkel, Fernando Henrique Cardoso, Andre Gunder Frank, Enzo Faletto, Arghiri Emmanuel, Samir Amin, Jose Gabriel Palma ve Immanuel Wallerstein'dir (Tüylüoğlu, 2004: 260). Bağımlılık teorisinin gelişimine bakıldığında üç ana akım içerisinde geliştiği gözlenmektedir. Bunlar, marksist düşüncenin dolaylı bir yansıması olan "neo-sömürgeci bağımlılık okulu", "yanlış paradigma modeli" ve "ikili kalkınma tezi"dir. Neo-sömürgeci bağımlılık okuluna göre, üçüncü dünya ülkelerinin geri kalmışlığı ve yoksulluğu zengin-yoksul ülke ilişkilerine dayanan ve eşit olmayan uluslararası kapitalist sistemin tarihsel gelişim sürecine bağlıdır. Yanlış paradigma modeline göre, az gelişmiş ülkelerin geri kalmışlığı ve yoksulluğu gelişmiş ülke merkezli otoritelerin yoksullukla mücadeleye yönelik yanlış politika önerileri ile ilişkilendirilmektedir. Gerek ulusal ve/veya uluslararası yardım kuruluşlarının gerekse çok uluslu şirketler ile uluslararası mali kurumların yoksullukla mücadele politikası önerileri az gelişmiş ülkelerin yapısal özelliklerini dikkate almayıp, toptancı bir yaklaşımla hazırlanmıştır. Dolayısıyla standart politikalar farklı yoksulluk gerekçelerine sahip ekonomilerde aynı etkiyi göstermede başarılı olamamıştır (Solmaz, 2008). Üçüncü ve son akım olan ikili kalkınma tezine göre ise, geri kalmışlık ve yoksulluk çevre ve merkez ülkeler arasındaki geçmişten günümüze devam eden ekonomik ilişkilerin sonucudur (Tokatlıoğlu \& Selen, 2017: 286; Solmaz, 2008). Çevre ülkeler üzerinde oluşturulan merkez ülke egemenliği, çevre ülkelerin ekonomilerinde aşırı düzeyde çarpıtma, biçimsizleştirme ve eklemsizleştirme ortaya çıkarmaktadır. Çevre ülkelerde 
gerçekleşen kapitalist yayılma bu ülkelerde iç bütünlüğün bozulmasına yol açarken gelişmenin yolunu tıkamaktadır. Bunun sonucu olarak dışa dönük gerçekleşen büyüme merkezin ihtiyaçları doğrultusunda yönlendirilmektedir (Başkaya, 2004: 84-85). Bunun sonucunda çevre ülkelerin ekonomik yapıları, merkez ülkelerin sermayesinin faaliyet gösterdiği ihracat sektörü lehine oluşmuştur (Amin, 1973: 192).

Bağımlılık teorisi 1950'lerde Paul Baran tarafından az gelişmiş ülkeler ile gelişmiş ülkeler arasındaki ilişkiler bağlamında geliştirilmiştir. P.Baran'a göre, az gelişmiş ülkelerin kalkınmaları gelişmiş ülkelerin çıkarlarına ters düşmektedir. Gelişmiş ülkelerin ihtiyaç duydukları önemli hammaddeleri gönderen, bu ülkelerin şirketlerine büyük karlar ve yatırım alanları sağlayan az gelişmiş ülkeler, gelişmiş ülkeler için her zaman vazgeçilmez bir hinterlant olmaktadır. Bu nedenle $A B D$ ve diğer gelişmiş ülkeler kaynak ülkeleri olarak adlandırılan az gelişmiş ülkelerin sanayileşip kalkınmalarına karşı çıkmakta ve bunun için her türlü engeli çıkarmaktadırlar. P.Baran'a göre, az gelişmişlik kapitalist gelişimin alternatif maliyetini oluşturmaktadır. Bu alternatif maliyet ekonomik faaliyet sürecinde yaratılan katma değerin, ticari ilişkiler yoluyla, görece olarak az gelişmiş ülkelerden gelişmiş ülkelere orantısız biçimde aktarılmasının sonucunda ortaya çıkmaktadır. Uluslararası ekonomik ilişkilerde ortaya çıkan katma değerin gelişmiş ülkelerde yoğunlaşması diğer ülkelerin yoksullaşması sonucunu doğurmaktadır. Gelişmişlik ve az gelişmişlik bir madalyonun iki yüzü olarak kabul edilmektedir. Baran (1957); gelişmiş ülkelerin, bir yandan az gelişmiş ülkelerin kalkınmalarının önünde engeller yaratırken, diğer taraftan da bu ülkelerin kalkınmalarının sağlanması gerekliliği yönündeki söylemleri siyasi ve ideolojik hile olarak nitelendirilmektedir. Az gelişmiş ülkelere verilen kalkınma yardımlarının asıl amacının bu ülke halklarının yaşam düzeyini yavaş ve kademeli olarak yükselterek toplumun sanayileşme talebinin azaltılması ve sosyo-ekonomik ilerlemenin yavaşlatılması olarak değerlendirilmektedir (Baran, 1957: 120-122).

P.Baran'ın görüşlerinden etkilenen A.G.Frank, büyük şirketlerin, çekirdek bölgelerdeki büyük devletlerin ve dünya ekonomisinde "serbest ticaret"i teşvik eden uluslararası kuruluşların politikalarının sonuçlarını tanımlamak için geliştirmiş olduğu $a z$ gelişmişliğin gelişmesi (the development of underdevelopment) kavramı ile bağımlılık okulunun 1970'lerde popüler olmasında önemli bir yere sahiptir (Ercan, 2003: 134; Wallerstein, 2004: 12). A.G.Frank, P.Baran gibi az gelişmişliğin kapitalist gelişimden önce olmadığını ve kapitalist yayılmayla birlikte var olan bir olgu olduğunu ifade etmektedir. Çoğu bağımlılık teorisyeni gibi A.G.Frank da gelişmiş ülkelerin gelişmesini ve diğer ülkelerin gelişmemesini, oluşan artığın sömürü yoluyla az gelişmiş ülkelerden gelişmiş ülkelere aktarılmasına bağlamaktadır. A.G.Frank'ı P.Baran'dan ayıran önemli nokta, ekonomik artığın aktarılmasını metropol - uydu ilişkisine dayandırmasıdır. Metropol ülkeler gelişmiş ülkeler iken uydu ülkeler ise az gelişmiş ülkelerdir. Buna göre uydular yalnızca metropollerin çıkarlarıyla ters düşmediği sürece ve metropollerin izin verdiği oranda kalkınabilmektedirler (Frank, 1967: 3). Metropoller, uyduların ekonomik artıklarına sömürü yoluyla el koyarak kalkınırken, uydular ise geri kalmaktadır. Özetle 
A.G.Frank az gelişmişliğin metropol ve uydu ilişkilerinin tarihsel bir ürünü olduğunu, metropol - uydu ilişkilerinin kapitalist dünya düzeninden kaynaklandığını ve uyduların gelişmelerinin ancak metropollerin zayıf olduğu Büyük Buhran ve Dünya Savaşları gibi dönemlerde sınırlı şekilde gerçekleştiğini ifade etmektedir (Chilcote, 1974: 14):

Samir Amin ise Frank'tan farklı olarak, kapitalizmi merkez ve uydu olmak üzere iki kategoride inceler. Merkezdeki ekonomik birimler arası ilişkiler içsel olarak dengeli bir karaktere sahipken, uydudaki ekonomik birimler arası ilişkiler ise merkez tarafından dışarıdan yönlendirildiği için merkezdeki birikimin mantığına tabidirler (Erdoğan, 2000: 163). Kapitalist birikim mantığının uydu ülkelerde hâkim kılınması, bu ülkelerde iç bütünlüğü ve tutarlılığı olmayan bir ekonomik yapı oluşturarak gelişmenin yolunu tıkamaktadır (Başkaya, 2004: 84). Bu da ekonomik büyümeyi dışa bağımlı kılmaktadır. Dışa dönük bağımlı büyüme uydudaki büyüme ve gelişmenin merkezin şekillendirdiği biçimde gerçekleşmesine imkan sağlamaktadır (Amin, 1973: 203). Yani merkezin istek ve ihtiyaçları doğrultusunda büyüme ve gelişme sağlanmaktadır. Çevrenin ticaretinin büyük bölümü merkez ile gerçekleştirilirken merkez ekonomiler aksine ticareti kendi aralarında yoğun olarak gerçekleştirmektedirler. Aynı zamanda çevre ülkelerde merkez menşeili yabancı sermaye yatırımları otomatik olarak ters yönde bir kar transferi yarattıklarından dolayı oluşan çevrenin merkeze olan mali bağımlılığı beraberinde ticari bağımlılığı da getirmektedir (Amin, 1973: 246-260). S.Amin'e göre uydu ülkeler merkez ülkelere bağımlı olarak kaldığı sürece kalkınma hedeflerini gerçekleştiremeyeceklerdir. $\mathrm{Bu}$ nedenle de uydu ülkeler merkezden kopmalıdır. Bu kopuş otarşi anlamında bir kopuş değil, uydu ülkelerdeki ekonomik faaliyetlerdeki işleyişin merkezden değil içerden düzenlenmesi şeklinde bir kopuşla gerçekleştirilmelidir (Başkaya, 2004: 88).

Immanuel Wallerstein dünya sistemi kuramını geliştirmiştir. Buna göre Baran, Frank ve Amin gibi bağımlılık teorisinin önde gelen isimlerinden farklı olarak bağımlılık teorsinin varsayımlarını değiştirmiştir. Buna göre dünya sistemi kapitalist dünya sistemidir. I.Wallerstein'a göre, kapitalizm 16. yüzyıldan bu yana vardır ve merkez, yarı çevre ve çevre olmak üzere üç bölgede toplanır (Wallerstein, 2004: 17). Merkez, kapitalist sistemin egemen gücüdür ve yarı çevre ile çevrenin ekonomik artıklarını sömürmektedir. I.Wallerstein'e göre, yarı çevre ve çevre ülkelerde sosyo-ekonomik yapı, dünya pazar fırsatları, teknolojik üretim olanakları tarafından belirlenmekte ve devlet yapısı ile politikaları egemen güçlerin çıkarlarına göredir. I.Wallerstein, bu durumdan kurtulmanın tek yolunun merkez ile ilişkilerin kesilmesi olduğunu söylemektedir (Erdoğan, 2000: 161). Buradan hareketle, dünyada gerçekleşen devrimci hareketlerin nedeninin merkezin baskıc tutumuna son verme ve devletler bazında bu devrimci hareketlerin ülkelerinde gerçek anlamda kalkınmanın gerçekleştirilebileceği yönündeki beklentiler olduğu ifade edilmektedir (Aslan, 2013: 183).

Polonyalı iktisatçı Oskar Lange'nin, "Az gelişmiş ülkelerin sorunlarını çözmede kapitalist bir yolu olanaksız kılan ve bu ülkeleri başka iktisadî gelişme yollarına zorlayan şey neydi?" sorusuna şu şekilde yanıt vermiştir. "Tekelci kapitalizm ve emperyalizm, 
azgelişmiş ülkelerin geleneksel kapitalist gelişme yolunu izlemelerine olanak bırakmamıştır. Bunun çok nedeni var. En önemlisi şudur: En başta gelen kapitalist ülkelerde, büyük kapitalist tekellerin gelişmesiyle, buralardaki kapitalistler daha az gelişmiş ülkelerdeki gelişme sağlayıcı yatırımlara ilgi duymaz oldular; çünkü bu türlü yatırımlar, bunların sağlam tekelci durumlarını tehdit edebilecek bir rekabetin doğmasına yol açabilirdi. Bunun sonucu olarak, gelişmiş ülkelerin az gelişmiş ülkelerdeki yatırımları özel bir karakter kazanmıştı. Bu yatırımların başlıca hedefi, gelişmiş ülkeler endüstrilerinin ham madde olarak kullandığı doğal kaynakların sömürülmesi ve gelişmiş ülkelerdeki nüfusu beslemek için azgelişmiş ülkelerde besin maddeleri üretimini geliştirmekti... Sonuç olarak, azgelişmiş ülkelerin ekonomileri tekyönlü ham madde ve besin maddeleri ihraç eden ekonomiler haline gelmiştir. Bu ülkelerde yabancı sermayenin elde ettiği kârlar tekrar bu ülkelerdeki yatırımlar için kullanılmamış, ana sermayelerin geldiği ülkelere dönmüştür. Bu kârlar, modern iktisadî gelişmenin gerçek dinamik etkeni olduğunu bildiğimiz herhangi büyük çaplı bir sanayi yatırımı için kullanılmamıştır. Azgelişmiş ülkelerin klâsik kapitalist kalkınma yolunu izleyememelerinin temel nedeni budur (Dobb, 1981: 123-124)".

Her nasıl açıklanırsa açıklansın bağımlılık teorisi, az gelişmişliğin kapitalizmin gelişim sürecinde ortaya çıkan bir olgu olduğunu savunmaktadır. Gelişmiş ülkelerin gelişme süreçleri aynı zamanda az gelişmiş ülkelerin az gelişmişlik nedenini ve sürecini oluşturmaktadır. Özellikle sanayi devrimini takiben hızlanan ülkeler arası gelişmişlik farklılıkları az gelişmişlik olgusunu ortaya çıkarmıştır. Ülkeler arası dış ticaret hadlerinin gelişmiş ülkeler lehine dönmesi, gelişmişlik farklılıklarının sürekli biçimde artmasına neden olmuştur. Bu bakış açısıyla yaklaşıldığında yoksulluk ve az gelişmişliğin kapitalist yayılmanın bir sonucu olduğunu söylemek yanlış olmayacaktır. Bağımlılık teorisine göre Ricardo'nun ortaya koyduğu karşılaştırmalı üstünlükler teorisi eleştirilerek, uluslararası ticaretin eşitler arasında yapılmadığı ve katma değerin çevreden merkeze eşit olmayan biçimde aktarıldığı ifade edilmektedir (Wallerstein, 2004: 12).

\section{DTÖ Kapsamında Korumacılık Politikası Araçları}

1973 yılında ortaya çıkan Petrol Krizi, uluslararası ticaretin serbestleştirilmesi yönündeki genel eğilimi, 1929 yılında yaşanan Büyük Buhrandan beri dünyanın en derin küresel durgunluğuna çevirmiştir. 1980'li yıllardan itibaren dünya ticaretine yön veren en önemli gelişme neo-liberal politikalar olmuştur. Washington Uzlaşısı kavramı 1989 yılında ilk kez John Williamson tarafından kullanılmış olup, bu uzlaşı sonrası neoliberal politikaların popülerliği artmıştır. Washington Uzlaşısı neoliberal politikaların en büyük savunucusu olan $A B D$ ve kuruluşunda etkili olduğu IMF ve DB arasında az gelişmiş ülkelerin kalkınmalarını sürdürebilmeleri ve dünya piyasalarına entegre olarak uluslararası sermaye hareketlerinden daha fazla yararlanmalarını sağlamak amacıyla gerçekleştirilmiştir (Mangır \& Acet, 2014: 96). Yukarıda da bahsedildiği üzere gelişmiş ülkeler az gelişmiş ülkelerin kalkınmaları yönünde beyanatta bulunmalarına rağmen, 
gerçekte bu ülkelerin dünya pazarlarına entegre olmalarını sağlayarak ekonomik fazlaları kendi ülkelerine çekmek istemektedirler. 1995 yılına gelindiğinde neoliberal politikaların savunucusu ve uygulayıcısı olan üç önemli ayağın sonuncusu DTÖ kurulmuştur. DTÖ, IMF ve DB gibi kuruluşlar aracılığıyla merkez ülkeler, çevre ülkelerden tek taraflı tavizler elde etmektedirler. Bu da doğu bloğundaki komünist sosyalist dünya görüşünün karşısında batı bloğunun liberal kapitalist bakış açısının somut bir göstergesidir (Kazgan, 2015: 130-131; Ateş, 2016: 212-213). Günümüzde IMF, DB ve DTÖ gibi uluslararası kuruluşlar az gelişmiş ve gelişmekte olan ülkelerde neoliberal politikaların uygulanmasının teşvik edilmesinde önemli rol oynamaktadır (Chang \& Grabel, 2005: 47).

Literatüre bakıldığında serbest ticaretin ülkelerin ve dünya refahının artırılmasında rolü bulunmaktadır. Zaten dünyada hiçbir ülke kendine yetecek kaynaklara sahip değildir. Bu nedenle de diğer ülkelerle ticaret yapmak zorundadır. 0 halde uluslararası ticaretin önündeki engellerin azaltılarak veya kaldırılarak serbest ticarete doğru atılan her adım dünya refahını artırıcı etkide bulunmaktadır. Dünya refahını artırıcı serbest ticaret politikaları "birinci en iyi" politikalar olarak adlandırılmaktadır (Seyidoğlu, 2003: 214-215). Birinci en iyi politikaların en önemli varsayımlarından birisi, özel maliyet ile sosyal maliyet arasında fark olmamasıdır. Fakat bu varsayım çoğu zaman serbest ticarette, ihracatçı firma veya ülke davranışlarından kaynaklanan damping ve sübvansiyon uygulamaları, ithalatçı ülkenin iç piyasa yapısı ve yasal düzenlemeleri ile ihraç pazarlarında yaşanan rekabet (Selen \& Gümüş, 2011: 215) gibi ticareti saptırıcı piyasa başarısızlıkları nedeniyle gerçekleşmemektedir. Aynı zamanda küresel kriz döneminde gelişmiş ülkelerin uygulamış oldukları korumacılık politikalarının toplam uygulamalar içerisinde oranının yüksek olması dünya piyasalarında bozucu etki yaratmakta ve piyasa aksaklıklarına neden olmaktadır (Öz, 2009: 6). Piyasa aksaklıklarının varlığı durumunda tam rekabet koşulları oluşmamakta ve sadece ticaretin serbestleştirilmesiyle üretim ve tüketimde Pareto optimali sağlanamamaktadır. Pareto optimalinin sağlanabilmesi için yani tam rekabet ve serbest ticaret politikalarının gerçekleşmediği bir ortamda piyasadaki mevcut engellemeleri dengeleyecek yeni müdahale araçlarının konulması "ikinci en iyi" politikayı oluşturmaktadır (Seyidoğlu, 2003: 214-215). Buradan hareketle korumacılık politikalarına piyasa aksaklıklarının görüldüğü dönemlerde ve alanlarda izin verilebilmektedir.

DTÖ kapsamında üye ülkeler yukarıda bahsedilen piyasa aksaklıklarına karşı Ticaret Politikası Savunma Araçlarını kullanmaktadırlar. Ticaret Politikası Savunma Araçları, "DTÖ ilgili Anlaşmalarında ve İthalat Rejimi Kararının 4. Maddesinde iç mevzuatta yer alan, benzer veya doğrudan rakip mallar üreten yerli üreticilerin ithalattan (ciddi) zarar görmesinin önüne geçmek amacıyla başvurulan, dampinge karşı önlemler, sübvansiyona karşı önlemler ile korunma ve gözetim önlemlerinin tamamına verilen genel isimdir." 
Damping, bir malın normal değerinden yani ihracatçı veya menşe ülkedeki iç piyasa satış fiyatından daha düşük bir fiyatla ihraç edilmesidir. Bu durum, ya ihracata verilen bir çeşit devlet desteğinin olduğunu ya da ihracatçının bir tür fiyat farklılaştırma politikası uyguladığını gösterir (Kalaycıoğlu, 1991: 61). Bir ülkedeki ihracatçı firmaların mallarını kendi ülkelerindeki satış fiyatından daha düşük bir fiyatla satmaları, uluslararası ticarette haksız rekabet olarak adlandırılmaktadır (Başkol, 2010: 107). DTÖ Anti-Damping Anlaşması Madde 1 gereği GATT 94 Madde 6'da öngörülen dampingin varlığının yanı sıra yerli üreticinin zarar gördüğünün ve bu zararın dampingli ithalat ile bağının bulunduğunun anlaşılması durumunda karşı önlemin alınabileceği hükme bağlanmıştır (Madde 1). Yani, dampingli satış ile ilgili yapılan soruşturmalar neticesinde malın ülkeye dampingli olarak satışının yapıldığına kanaat getirilirse, DTÖ Antidamping Anlaşması hükümleri gereğinde antidamping vergisi uygulanabilmektedir.

Sübvansiyon ise, menşe veya ihracatçı ülkenin fayda sağlayan, doğrudan veya dolaylı mali katkısı veya GATT 1994'ün 16. maddesi çerçevesinde herhangi bir gelir veya fiyat desteği olarak tanımlanmaktadır. Sübvansiyona konu olan ithalata karşı önlem alınabilmesi için sübvansiyonun, Sübvansiyonlar ve Telafi Edici Tedbirler Anlaşması'na göre yasaklanmış veya önlem alınabilir sübvansiyonlardan olması gerekir. Sübvansiyon soruşturması sonucu sübvansiyonun, yerli üretim dalında maddi zararın ve her ikisi arasında illiyet bağının tespit edilmesi neticesinde sübvansiyona karşı telafi edici önlemler alınabilmektedir. Damping firma kaynaklı haksız rekabet unsuru iken, sübvansiyon devlet kaynaklı haksız rekabet unsurudur.

Bir malın üreticisi yerli sanayinin uluslararası piyasalarda rekabet edebilecek düzeye gelinceye kadar sınırlı ve geçici olmak kaydıyla korunma önlemi alınabilmektedir. Bu amaçla, korunma önlemi bir malın ithalatında uygulanmakta olan gümrük vergilerinde artış yapılması veya miktar sınırlaması şeklinde uygulanabileceği gibi bunların kombinasyonu olarak da uygulanabilmektedir. DTÖ Kurucu Anlaşması ekinde yer alan ve dünya ticaretinin serbestleştirilmesi yönünde önemli etkileri olan ek anlaşmalar içerisindeki korumacılık politikası araçlarının üye ülkeler tarafından kullanımlarının analizi bir sonraki başlıkta anlatılacaktır. Anti-dampingde amaç haksız rekabetin bertaraf edilmesi iken, korunma önleminde amaç ise ortada haksız rekabet unsuru bulunmaksızın uluslararası pazarlarda rekabet edemeyen yerli üreticinin rekabet edebilecek düzeye gelinceye kadar belirli bir süre için korunmasıdır. Aynı zamanda anti-damping önlemi sadece damping yapan ülke ve/veya firmalara uygulanırken, korunma önlemi ise herhangi bir ayrım gözetmeksizin tüm ülkelere karşı uygulanabilmektedir (iTO, 2011: 10-11).

DTÖ anlaşmaları kapsamında uluslararası ticarette hiç bir üye ülke kendiliğinden bir önlem alamamaktadır. Öncelikle üye ülkeler DTÖ kapsamında şikâyette bulunarak soruşturma açılmasını talep etmektedirler. Soruşturma başladığında niteliğine göre yalnızca soruşturma süresince uygulanabilecek taahhüt ve geçici önlem uygulamaları gerçekleştirilebilmektedir. Taahhüt ihracatçı üye ülkenin ithalatçı üye ülkede zarar 
neden olan fiyat politikasından vazgeçeceğine dair beyanıdır. Geçici önlem ise, soruşturma tamamlanıncaya kadar geçen sürede ithalatçı ülkenin dampinge veya sübvansiyona konu ithalata gözetim kararı alınması veya geçici vergi alınması şeklindeki uygulamadır. Soruşturma sonucu ithalatçı ülkenin uğradığı zarar ile ithalat arasında bir bağın kurulması durumunda meydana gelen zararın ortadan kaldırılması amacıyla vergi uygulamasına gidilmektedir. Dampingli satışlarda anti-damping vergisi uygulanırken, sübvansiyona karşı ise telafi edici vergi uygulanmaktadır.

Bağımlılık teorisinde de belirtildiği gibi merkez ülkeler uyguladıkları politikalar ve kurallar ile çevre ülkelerin gelişmesini engellemektedir. Bu engelleme bazen doğrudan merkez ülkelerin uygulamış oldukları politikalar ile gerçekleşirken, bazen de uluslararası kuruluşların politikalarının belirlenmesi ve uygulanması sürecine müdahale yoluyla gerçekleşmektedir. Buradan hareketle neoliberal küreselleşme sonucu dünya ekonomik sistemine yön vermek amacıyla ABD önderliğinde oluşturulan IMF, DB ve DTÖ gibi kuruluşlar çevre ülkelere merkez ülkelerin çıkarları doğrultusunda politika belirleme ve uygulama konusunda baskı kurmaktadır. Bu şekilde devletin ekonomideki varlığı ve politika belirleme yetkisi uluslararası anlaşmalar nedeniyle kısıtlanarak, bağımlılık teorisinin temel varsayımlarından olan güçlü devletin varlığı ortadan kaldırımaya çalışımaktadır. Bu gibi uluslararası sınırlamalar nedeniyle, devletler "kukla devlet" konumuna dönüştürülmeye çalışılmaktadır (Aslan, 2013: 180-182). Chang yapmış olduğu çalışmada, gelişmiş ülkelerin gelişmekte olan ülkeler ve az gelişmiş ülkelere hem tavsiye ettikleri politikalar hem de kapitalist amaçla oluşturulan uluslararası kuruluşlar aracılığıyla uygulatmaya çalıştıkları politikaların 1960 - 1980 döneminde kötü politika olarak nitelendirilmesine rağmen 1980 - 2000 dönemindeki iyi olarak nitelendirilen politikalardan daha başarılı olduğu sonucuna ulaşmıştır (Aslan, 2013: 184). Gelişmiş ülkeler bir yandan dünya ticaretinin serbestleştirilmesi için DTÖ aracılığıyla girişimlerde bulunurken, diğer taraftan da az gelişmiş ve gelişmekte olan ülkelerin dünya pazarındaki hareket alanlarını kısıtlayıcı bir takım mekanizmaları bünyesinde bulunduran DTÖ’nün bu mekanizmalarını kendi çıkarları doğrultusunda kullanmaktadırlar. DTÖ’de karar alma mekanizması her ne kadar eşit oy ilkesine göre işlese de $A B D, A B$, Japonya ve Kanada tarafından yönlendirilen resmi olmayan toplantılarda gündem ve karar belirlenmektedir (Woods \& Narlikar, 2001: 573). Baran'ın ifade ettiği gibi merkezde yer alan ülkeler bir taraftan serbest ticaretin gelişme için tek yol olduğu yönündeki söylemleri ile kaynak ülkelerin dünya ticaretine entegre olmasını sağlarken diğer taraftan da kendi sanayilerini kaynak ülkelerinin üstünlüğe sahip olduğu sektörlerden koruma yoluna giderek siyasi ve ideolojik hileye başvurmaktadırlar. Çevre ülkelerin dünya ticaret sistemine entegre olmalarının sağlanmasındaki amaç merkez ülkelerin ürettikleri mallarına pazar yaratma isteğidir. Merkezle çevre arasındaki ilişkiler temelde eşit bir şekilde gerçekleşmemektedir (Amin, 1973: 253). Dolayısıyla merkez ülkeler kendi mallarına pazar yaratırken çevre ülkelerden gelecek mal hareketlerine karşı DTÖ kapsamında korumacılık politikaları uygulamasına gitmektedir. Böylece çevre ülkeler dış açıkla karşı karşıya kalmakta ve dış 
açığın kapatılması amacıyla merkezdeki ve merkezin kontrolündeki uluslararası kuruluşlardaki birikime gerek duyulduğundan çevre merkezin isteği doğrultusunda biçimlenmektedir (Amin, 1973: 253). Bunun sonucunda kendi gelişmeleri pahasına çevre ülkeleri uluslararası sistemin bir parçası olma bağımlılığına iterek az gelişmişliğe mahkûm bırakmaktadırlar. Bu durumla ilgili olarak P.Baran 1949 yılında dünya gelir dağılımı ile ilgili tespitlerde bulunduğu çalışmasında, yüksek gelirli ülkelerin dünya gelirinin $\% 67$ 'sine sahipken, dünya nüfusunun $\% 18$ 'ine, orta gelirli ülkelerin dünya gelirinin \%18'ine sahipken, dünya nüfusunun \%15'ine düşük gelirli ülkeler ise dünya gelirinin \%15'ine sahipken, dünya nüfusunun \%67'sine sahip olduğunu ifade etmiştir (Baran, 1957: 267). İngiliz yardım kuruluşu olan Oxfam'ın 2014 verilerine göre, en zengin \%1'lik dilimde bulunan kişilerin varlıkları dünya gelirinin \%48'ine karşılık gelirken, \%46'lik kısmı dünya nüfusunun \%20'sinin ellerinde ve kalan yaklaşık \%6'lik kısım ise, toplam dünya nüfusunun \%80'i arasında dağılmaktadır. Dünya nüfusunun çoğunluğunun az gelişmiş ülkelerde yer aldığı düşünülürse, dünya gelirinin çok azı bu ülkeler tarafından paylaşılmaktadır. Az gelişmiş ülkelerde kişi başına düşen gelir ise gelişmiş ülkelerde olduğundan çok düşük gerçekleşmektedir. Nurkse'nin de dediği gibi, "dünyanın geri kalmış denen ülkelerinin insan ırkının üçte ikisini meydana getirmekte olmaları başlı başına, hiç akıldan çıkarılmaması gereken, koskoca bir olgudur (Dobb, 1981: 123)."

\section{Korumacılık Politikası Araçlarının Kullanımı}

DTÖ’nün sahip olduğu iki mekanizma vardır. Bunlar, Anlaşmazlıkların Halli Mekanizması ve Ticaret Politikalarını İzleme Mekanizmasıdır. Anlaşmazlıkları Halli Mekanizması, üye ülkeler arasında ortaya çıkan anlaşmazlıkların DTÖ platformunda çözümünde önemlidir. Bu mekanizma dünya ticaret sistemini hukukileştirerek daha bağlayıcı bir zemine oturmasını sağlamakta ve DTÖ’ye "uluslararası ticaret mahkemesi" statüsü kazandırmaktadır. Diğer mekanizma olan Ticaret Politikalarını İzleme Mekanizması ise, uluslararası ticarette şeffaflığın sağlanması ve tüm üye ülkelerin birbirlerinin ticaret politikaları hakkında tam bilgiye sahip olmasını sağlamaktadır. Bu nedenle DTÖ’ye üye ülkeler ticaretle ilgili uygulamış oldukları veya uygulayacak oldukları politikaları DTÖ’ye bildirmek zorundadırlar. DTÖ ise bu durumu Ticaret Politikalarını İzleme Mekanizması aracılığı ile diğer tüm üye ülkelere bildirmektedir. Bu nedenle ticaret politikası savunma araçlarının kullanımı ile ilgili veriler DTÖ veri tabanından elde edilmiştir.

DTÖ kapsamında ticaret politikası savunma araçları korunma önlemleri, antidamping ve telafi edici vergiler olarak kabul edilmektedir. Ticaret politikası savunma araçlarının kullanımı ile ilgili veriler Tablo 1'de yer almaktadır. Ticaret politikası savunma araçlarının DTÖ kurallarına aykırı olarak kullanılması nedeniyle toplam 588 adet uyuşmazlık ortaya çıkmıştır. 
Korunma önlemlerinin kullanımı açısından ortaya çıkan anlaşmazlıklara bakıldığında toplamda en çok $A B D, A B$, Arjantin ve Şili aktif olarak kullanmaktadır. Tablolarda yer alan davacı verileri, üye ülkelerin DTÖ kurallarına aykırı korumacılık gerçekleştirdiği gerekçesiyle soruşturma başlatan ülkelerin sayısını, davalı verileri ise üye ülkelerin DTÖ kurallarına aykırı korumacılık gerçekleştirdiği gerekçesiyle hakkında soruşturma başlatılan ülke sayılarını göstermektedir. Buna göre, korunma önlemleri kapsamında ABD, tüm şikâyetçi başvuruların \%8,5'ini yaparken, toplam şikâyetin \%31,9'unu almıştır. AB'nin şikâyetçi olarak başlattığı davaların oranı \%12,8 iken, AB hakkında başlatılan toplam şikâyet oranı \%8,5'tir. Toplam korunma önlemleri soruşturmalarına $A B D \% 20,2$ oranında, $A B$ ise $\% 10,6$ oranında muhatap olmuştur.

Antidamping kapsamında anlaşmazlık sayılarına bakıldığında, mekanizmayı en aktif kullanan ülkeler, $A B D, A B$, Çin ve Meksika'dır. $A B D$, tüm şikâyetçi başvuruların \%6,2'sini yaparken, toplam şikâyetin \%42,7'sini almıştır. AB'de şikâyetçi olarak başlatılan davaların oranı \%12,4 iken, hakkında başlatılan toplam şikâyet oranı \%12,8'dir. Çin'de ise şikâyetçi olarak başlatılan davaların oranı \%9,3 iken, hakkında başlatılan toplam şikâyet oranı $\% 6,8^{\prime}$ dir. Toplam antidamping soruşturmalarda ABD $\% 23,6$ oranında, $A B \% 12,6$ oranında ve Çin ise $\% 8,1$ oranında muhatap olmuştur. Burada dikkat çeken önemli nokta $A B D$ hakkında başlatılan soruşturma sayısıdır. ABD uluslararası ticarette DTÖ kurallarına aykırı antidamping uygulamaları nedeniyle diğer üye ülkeler tarafından hakkında en çok dava açılan ülke olmuştur.

Haksız rekabet unsuru olan sübvansiyona karşı telafi edici vergi uygulamaları kapsamında sayılara bakıldığında, en aktif olan üyeler $A B D, A B$, Kanada ve Çin'dir. $A B D$, tüm şikâyetçi başvuruların \%25'ini yaparken, toplam şikâyetin \%30,6'sını almıştır. AB'de şikâyetçi olarak başlatılan davaların oranı \%18,5 iken, hakkında başlatılan toplam şikâyet oranı \%21,8'dir. Kanada'da şikâyetçi olarak başlatılan davaların oranı \%9,7 iken, hakkında başlatılan toplam şikâyet oranı \%8,1'dir. Çin'de ise şikâyetçi olarak başlatılan davaların oranı \%4 iken, hakkında başlatılan toplam şikâyet oranı \%12,9'dur.

Toplam sübvansiyona karşı telafi edici vergi uygulamaları soruşturmalarında ABD $\% 27,8$ oranında, $A B \% 20,1$ oranında Kanada \%8,9 ve Çin ise \%8,5 oranında muhatap olmuştur. DTÖ kapsamında başlatılan soruşturma sayılarına Türkiye özelinde bakılacak olunursa, toplam 6 dava sayısı ve genel dava sayısı içerisindeki \%1'lik oranla 16. sırada olduğu görülmektedir. Türkiye'nin DTÖ kapsamındaki ticaret politikası savunma araçlarına başvuru sayısının düşük olmasının nedeni, dünya ticaretinden aldığı pay ile paralel olarak düşük gerçekleştiği veya konuyla alakalı yeterli bilgiye sahip olmadığı şeklinde değerlendirilebilir. 
Tablo 1: DTÖ Kapsamında Ticaret Politikası Savunma Araçlarıın Kullanımı (1995:01 - 2017:10)

\begin{tabular}{|c|c|c|c|c|c|c|c|c|c|c|c|c|}
\hline & \multicolumn{3}{|c|}{ Korunma Önlemleri } & \multicolumn{3}{|c|}{ Antidamping } & \multicolumn{3}{|c|}{ Telafi Edici Önlemler } & \multicolumn{3}{|c|}{ GENEL TOPLAM } \\
\hline & Davacı & Davalı & Toplam & Davacı & Davalı & Toplam & Davacı & Davalı & Toplam & Davaci & Davalı & Toplam \\
\hline ABD & 4 & 15 & 19 & 8 & 50 & 58 & 31 & 38 & \begin{tabular}{|l|}
69 \\
\end{tabular} & 43 & \begin{tabular}{|l|}
103 \\
\end{tabular} & 146 \\
\hline AB & 6 & 4 & 10 & 16 & 15 & 31 & 23 & 27 & 50 & 45 & 46 & 91 \\
\hline Çin & 3 & 0 & 3 & 12 & 8 & 20 & 5 & 16 & 21 & 20 & 24 & 44 \\
\hline Kanada & 0 & 0 & 0 & 7 & 2 & 9 & 12 & 10 & 22 & 19 & 12 & 31 \\
\hline Brezilya & 1 & 0 & 1 & 8 & 2 & 10 & 12 & 7 & 19 & 21 & 9 & 30 \\
\hline Meksika & 1 & 0 & 1 & 11 & 6 & 17 & 5 & 5 & 10 & 17 & 11 & 28 \\
\hline Arjantin & 5 & 8 & 13 & 6 & 4 & 10 & 1 & 2 & 3 & 12 & 14 & 26 \\
\hline Hindistan & 1 & 1 & 2 & 8 & 4 & 12 & 6 & 3 & 9 & 15 & 8 & 23 \\
\hline Güney Kore & 2 & 1 & 3 & 9 & 2 & 11 & 7 & 1 & 8 & 18 & 4 & 22 \\
\hline Japonya & 4 & 0 & 4 & 7 & 0 & 7 & 8 & 2 & 10 & 19 & 2 & 21 \\
\hline Endonezya & 1 & 2 & 3 & 8 & 0 & 8 & 3 & 4 & 7 & 12 & 6 & 18 \\
\hline Şili & 3 & 8 & 11 & 1 & 1 & 2 & 2 & 0 & 2 & 6 & 9 & 15 \\
\hline Avus tralya & 1 & 0 & 1 & 1 & 2 & 3 & 2 & 3 & 5 & 4 & 5 & 9 \\
\hline Rusya & 0 & 0 & 0 & 4 & 1 & 5 & 3 & 0 & 3 & 7 & 1 & 8 \\
\hline Tayland & 0 & 0 & 0 & 4 & 1 & 5 & 1 & 1 & 2 & 5 & 2 & 7 \\
\hline Türkiye & 0 & 1 & 1 & 3 & 1 & 4 & 1 & 0 & 1 & 4 & 2 & 6 \\
\hline Guatemala & 2 & 0 & 2 & 1 & 2 & 3 & 1 & 0 & 1 & 4 & 2 & 6 \\
\hline Güney Afrika & 0 & 0 & 0 & 0 & 5 & 5 & 0 & 0 & 0 & 0 & 5 & 5 \\
\hline Pakistan & 0 & 0 & 0 & 2 & 1 & 3 & 1 & 1 & 2 & 3 & 2 & 5 \\
\hline Dominik Cum. & 0 & 4 & 4 & 0 & 0 & 0 & 0 & 0 & 0 & 0 & 4 & 4 \\
\hline Ekvator & 0 & 1 & 1 & 1 & 2 & 3 & 0 & 0 & 0 & 1 & 3 & 4 \\
\hline Kolombiya & 3 & 0 & 3 & 0 & 0 & 0 & 0 & 0 & 0 & 3 & 0 & 3 \\
\hline Kosta Rika & 1 & 0 & 1 & 2 & 0 & 2 & 0 & 0 & 0 & 3 & 0 & 3 \\
\hline Norveç & 2 & 0 & 2 & 1 & 0 & 1 & 0 & 0 & 0 & 3 & 0 & 3 \\
\hline Peru & 0 & 0 & 0 & 1 & 1 & 2 & 0 & 1 & 1 & 1 & 2 & 3 \\
\hline Vietnam & 1 & 0 & 1 & 2 & 0 & 2 & 0 & 0 & 0 & 3 & 0 & 3 \\
\hline Ukrayna & 0 & 1 & 1 & 1 & 1 & 2 & 0 & 0 & 0 & 1 & 2 & 3 \\
\hline Filipinler & 0 & 0 & 0 & 0 & 1 & 1 & 0 & 1 & 1 & 0 & 2 & 2 \\
\hline Honduras & 1 & 0 & 1 & 1 & 0 & 1 & 0 & 0 & 0 & 2 & 0 & 2 \\
\hline İs viçre & 1 & 0 & 1 & 1 & 0 & 1 & 0 & 0 & 0 & 2 & 0 & 2 \\
\hline Misir & 0 & 0 & 0 & 0 & 2 & 2 & 0 & 0 & 0 & 0 & 2 & 2 \\
\hline Polonya & 1 & 0 & 1 & 1 & 0 & 1 & 0 & 0 & 0 & 2 & 0 & 2 \\
\hline Trinidad Tobag & 0 & 0 & 0 & 1 & 1 & 2 & 0 & 0 & 0 & 1 & 1 & 2 \\
\hline Yeni Zelanda & 2 & 0 & 2 & 0 & 0 & 0 & 0 & 0 & 0 & 2 & 0 & 2 \\
\hline Bangladeş & 0 & 0 & 0 & 1 & 0 & 1 & 0 & 0 & 0 & 1 & 0 & 1 \\
\hline Belçika & 0 & 0 & 0 & 0 & 0 & 0 & 0 & 1 & 1 & 0 & 1 & 1 \\
\hline E Salvador & 1 & 0 & 1 & 0 & 0 & 0 & 0 & 0 & 0 & 1 & 0 & 1 \\
\hline Fas & 0 & 0 & 0 & 0 & 1 & 1 & 0 & 0 & 0 & 0 & 1 & 1 \\
\hline Slovakya & 0 & 1 & 1 & 0 & 0 & 0 & 0 & 0 & 0 & 0 & 1 & 1 \\
\hline Venezuela & 0 & 0 & 0 & 0 & 1 & 1 & 0 & 0 & 0 & 0 & 1 & 1 \\
\hline Yunanistan & 0 & 0 & 0 & 0 & 0 & 0 & 0 & 1 & 1 & 0 & 1 & 1 \\
\hline TOPLAM & 47 & 47 & 94 & 129 & 117 & 246 & 124 & 124 & 248 & 300 & 288 & 588 \\
\hline
\end{tabular}

Kaynak: DTÖ ve Ulus lararası Ticaret Merkezi (ITC) verilerinden yararlanılarak tarafımızca oluşturulmuştur. 
Tablo 2'de DTÖ’nün kurulduğu tarih olan 1995 yılından 2017 yılının Ekim ayına kadar Anlaşmazlıkların Halli Mekanizmasına konu olan dava sayıları görülmektedir. Toplamda 71 ülke davalara taraf olmuştur. DTÖ genelinde kabul gören ancak DTÖ kurallarına aykırı olarak uygulanan korumacılık politikası araçları ile ilgili olarak 1995 2017 Ekim döneminde toplam 1100 adet uyuşmazlık ortaya çıkmıştır. Tablo 2 incelendiğinde merkez ülke olarak adlandırılan en ileri teknolojiye sahip, ücretlerin en yüksek olduğu ülkeler olan $A B D$, Japonya, $A B$ ve Kanada gibi ülkelerin korumacılık politikası araçlarını en çok kullanan ülkeler olduğu görülmektedir. Toplamda ABD 239 adet, AB 181 adet, Çin 61 adet, Kanada 56 adet, Brezilya ve Hindistan 47 adet, Arjantin 42 adet ile korumacılık politikası araçlarını en etkili biçimde kullanmışlardır. $A B D$, tüm şikâyetçi başvuruların \%19,7'sini yaparken, toplam şikâyetin \%23,8'ini almıştır. AB'de şikâyetçi olarak başlatılan davaların oranı \%17,5 iken, hakkında başlatılan toplam şikâyet oranı \%15,4'tür. Çin'de şikâyetçi olarak başlatılan davaların oranı \%4 iken, hakkında başlatılan toplam şikâyet oranı \%7,1'dir. Kanada'da şikâyetçi olarak başlatılan davaların oranı \%6,3 iken, hakkında başlatılan toplam şikâyet oranı \%3,8'dir. Türkiye ise şikâyetçi başvuruların \%0,7'sini yaparken, toplam şikâyetin \%1,6'sını almıştır. Toplam dava sayıları içerisinde oranlara bakıldığında ise, ABD \%21,7, AB \%16,5, Çin \%5,5 ve Kanada \%5 oranıyla ilk sıralarda yer almaktadır. Türkiye ise toplam 13 dava sayısı ve $\% 1,2$ oranıyla 16 . sırada yer almaktadır.

Tablo 2: Anlaşmazlkkların Halli Mekanizmasma Konu Dava Sayıları (1995:01 - 2017:10)

\begin{tabular}{|c|c|c|c|c|c|c|c|c|c|c|c|}
\hline & \multicolumn{3}{|c|}{ Toplam Dava Sayıs I } & & \multicolumn{3}{|c|}{ Toplam Dava Sayısı } & & \multicolumn{3}{|c|}{ Toplam Dava Sayısı } \\
\hline & Davacı & Davalı & Toplam & & Davacı & Davalı & Toplam & & Davacı & Davalı & Toplam \\
\hline ABD & 109 & 130 & 239 & Honduras & 8 & 0 & 8 & Malezya & 1 & 1 & 2 \\
\hline $\mathbf{A B}$ & 97 & 84 & 181 & Panama & 7 & 1 & 8 & Uruguay & 1 & 1 & 2 \\
\hline Çin & 22 & 39 & 61 & Macaristan & 5 & 2 & 7 & Danimarka & 1 & 1 & 2 \\
\hline Kanada & 35 & 21 & 56 & Ekvator & 3 & 3 & 6 & Romanya & 0 & 2 & 2 \\
\hline Brezilya & 31 & 16 & 47 & Kosta Rika & 5 & 1 & 6 & Almanya & 0 & 2 & 2 \\
\hline Hindistan & 23 & 24 & 47 & Güney Afrika & 0 & 5 & 5 & Moldova & 1 & 1 & 2 \\
\hline Arjantin & 20 & 22 & 42 & Norveç & 4 & 0 & 4 & Bangladeş & 1 & 0 & 1 \\
\hline Meksika & 24 & 14 & 38 & İsviçre & 4 & 0 & 4 & E Salvador & 1 & 0 & 1 \\
\hline Japonya & 23 & 15 & 38 & Misir & 0 & 4 & 4 & Fas & 0 & 1 & 1 \\
\hline Güney Kore & 17 & 16 & 33 & Polonya & 3 & 1 & 4 & Küba & 1 & 0 & 1 \\
\hline Endonezya & 11 & 14 & 25 & Fransa & 0 & 4 & 4 & Singapur & 1 & 0 & 1 \\
\hline Şili & 10 & 13 & 23 & \begin{tabular}{|l|} 
Vietnam \\
\end{tabular} & 3 & 0 & 3 & \begin{tabular}{|l|} 
Sri Lanka \\
\end{tabular} & 1 & 0 & 1 \\
\hline Avustralya & 7 & 16 & 23 & Belçika & 0 & 3 & 3 & Portekiz & 0 & 1 & 1 \\
\hline Tayland & 13 & 4 & 17 & \begin{tabular}{|l|} 
Slovakya \\
\end{tabular} & 0 & 3 & 3 & İsveç & 0 & 1 & 1 \\
\hline Rusya & 5 & 9 & 14 & \begin{tabular}{|l|} 
Venezuela \\
\end{tabular} & 1 & 2 & 3 & İtalya & 0 & 1 & 1 \\
\hline Türkiye & 4 & 9 & 13 & Birleşik Krallık & 0 & 3 & 3 & Bolivya & 0 & 1 & 1 \\
\hline Guatemala & 9 & 2 & 11 & İrlanda & 0 & 3 & 3 & Hurvatistan & 0 & 1 & 1 \\
\hline Ukrayna & 7 & 4 & 11 & Hollanda & 0 & 3 & 3 & Ermenistan & 0 & 1 & 1 \\
\hline Filipinler & 5 & 6 & 11 & Çek Cumhuriyeti & 1 & 2 & 3 & BAE & 0 & 1 & 1 \\
\hline Kolombiya & 5 & 5 & 10 & Nikaragua & 1 & 2 & 3 & Bahreyn & 0 & 1 & 1 \\
\hline Yeni Zelanda & 9 & 0 & 9 & \begin{tabular}{|l|} 
İspanya \\
\end{tabular} & 0 & 3 & 3 & Suudi Arabistan & 0 & 1 & 1 \\
\hline Pakistan & 5 & 3 & 8 & Katar & 3 & 0 & 3 & Kazakistan & 1 & 0 & 1 \\
\hline Dominik Cum. & 1 & 7 & 8 & Yunanistan & 0 & 3 & 3 & Antigua Barbuda & 1 & 0 & 1 \\
\hline Peru & 3 & 5 & 8 & Trinidad Tobago & 0 & 2 & 2 & TOPLAM & 554 & 546 & 1100 \\
\hline
\end{tabular}

Kaynak: https://www.wto.org/english/tratop_e/dispu_e/dispu_status_e.htm (01.11.2017) 
Tablo 3'te DTÖ kapsamında davalara taraf olan ülkelerden bazılarının 2016 yılı itibariyle dünya ticaretinden aldıkları pay yer almaktadır. Buna göre ülkelerin dava sayıları ile dünya ticaretinden aldıkları paylar arasında doğru yönlü bir ilişkinin var olduğu söylenebilir.

Tablo 3. Dünya Ticaretinden Alınan Paylar (2016)

\begin{tabular}{|c|l|c|c|l|c|}
\hline Sıra & \multicolumn{1}{|c|}{ Ülke } & $\begin{array}{c}\text { Dünya } \\
\text { Ticaretindeki Payı }\end{array}$ & Sıra & Ülke & $\begin{array}{c}\text { Dünya } \\
\text { Ticaretindeki Payı }\end{array}$ \\
\hline $\mathbf{1}$ & AB & $33.13 \%$ & $\mathbf{9}$ & Rusya & $1.47 \%$ \\
\hline $\mathbf{2}$ & Çin & $17.01 \%$ & $\mathbf{1 0}$ & Tayland & $1.28 \%$ \\
\hline $\mathbf{3}$ & ABD & $11.60 \%$ & $\mathbf{1 1}$ & Avustralya & $1.19 \%$ \\
\hline $\mathbf{4}$ & Japonya & $3.92 \%$ & $\mathbf{1 2}$ & Türkiye & $1.07 \%$ \\
\hline $\mathbf{5}$ & Güney Kore & $2.82 \%$ & $\mathbf{1 3}$ & Brezilya & $1.01 \%$ \\
\hline $\mathbf{6}$ & Kanada & $2.48 \%$ & $\mathbf{1 4}$ & Endonezya & $0.88 \%$ \\
\hline $\mathbf{7}$ & Meksika & $2.38 \%$ & $\mathbf{1 5}$ & Şili & $0.37 \%$ \\
\hline $\mathbf{8}$ & Hindistan & $1.93 \%$ & $\mathbf{1 6}$ & Arjantin & $0.36 \%$ \\
\hline
\end{tabular}

Kaynak: http://www.trademap.org/tradestat/index.aspx (01.11.2017)

I.Wallerstein'in dünya sistemi kuramında da bahsettiği merkez - yarı çevre çevre arasındaki ilişki $A B D, A B$ ve Japonya ile diğer ülkeler arasında da görülmektedir. Gerek $A B D$ gerekse $A B$ neoliberal politikalar kapsamında dış ticaretin serbestleştirilmesi ile ilgili politikaların tüm dünyada hâkim olması gerektiği yönünde ısrarcı olurlarken, aynı zamanda da bu ülkelerin korumacılık politikalarını yoğun şekilde kullanmalarıdır. Neoliberal politikaların başta da belirtilen gelişmiş ülkelerin serbest dış ticaret ile geliştikleri yönündeki söylemlerinin burada geçerli olmadığı görülmektedir. Gelişmiş merkez ülkelerin uluslararası kuruluşlar aracıllğıyla az gelişmiş çevre ülkelere dayattıkları, piyasaların serbestleştirilmesi yönündeki politikalar sayesinde az gelişmiş ülke pazarlarına giriş daha kolay ve daha güvenli biçimde gerçekleştirilebilmektedir. DTÖ bağlamındaki korumacılık mekanizmaları esasen piyasaları tam rekabet piyasalarına yaklaştırma amacını gütmektedir. Ancak, araçların kullanım etkinliğine bakıldığında gelişmiş ülkeler yerli sanayilerini koruma adına diğer ülkelere göre daha etkin kullanırken, aynı zamanda serbest piyasa temelli kuralları da en çok ihlal ettikleri iddiası ile de karşı karşıya kaldıkları gözlenmektedir. Bu açıdan bakıldığında gelişmiş ülkelerin kalkınmalarını serbest piyasa ekonomisi içinde sağladıkları argümanı tartışmaya açık bir hal almaktadır. Yukarıda korumacılık araçlarının kullanımına ilişkin istatistikler dikkate alındığında bu tartışma gelişmiş ülkelerin korumacılık politikaları sayesinde kalkınma süreçlerini tamamladıkları ve elde ettikleri üstünlükleri de serbest piyasa yüceltmesi altında korumaya çalıştıkları söylenebilir. 


\section{Sonuç}

Neo-liberal küreselleşme sürecinde neo-liberal politikaların uygulanması meşrulaştırılmaya çalışılmaktadır. Bu kapsamda gelişmiş ülkelerin serbest piyasa ekonomisi aracılığıyla geliştiklerine dair söylemlerle serbest piyasa ekonomisi yüceltilmeye çalışılmaktadır. Tarihsel gelişime bakıldığında aslında gelişmiş merkez ülkelerin üstünlük sahibi olduğu mallarda serbest ticareti savunurken, üstünlüğe sahip olmadıkları mallarda ise korumacılık politikalarını uyguladıkları görülmektedir. Buradan hareketle merkez gelişmiş ülkelerin önderliğinde dünya ticaret sisteminin serbestleştirilmesi amacıyla oluşturulan DTÖ, neoliberal küreselleşmenin önemli bir ayağını oluşturmaktadır. Ancak neo-liberal küreselleşme sürecine tepki olarak ortaya çıkan bağımlılık teorisine göre, gelişmiş merkez ülkelerin kalkınma süreçleri azgelişmiş çevre ülkelerin gelişememe sürecini oluşturmaktadır. Gelişmiş merkez ülkeler bir yandan dünya ticaretinin serbestleştirilmesi için DTÖ aracılığıyla girişimlerde bulunurken diğer taraftan da DTÖ’nün ülkelerin dünya pazarındaki hareket alanlarını kısıtlayıcı mekanizmalarından aktif biçimde yararlanmaktadır. Bu da P.Baran'ın ifade ettiği siyasi ve ideolojik hile kapsamına girmektedir. Tablolarda da görüldüğü üzere DTÖ kurallarına aykırı olarak korumacılık politikalarını aktif bir şekilde kullanan yine merkez ülke olarak adlandırılan $A B D, A B$ ve Japonya gibi ülkelerdir. DTÖ’nün karar alma mekanizması her ne kadar ülke başına bir oy şeklinde ise de başkanın daima ABD kökenli olması DTÖ kararlarında ABD'nin ve diğer merkez ülkelerin etkisinin yüksek olduğu şeklinde yorumlanabilir. Bu nedenle de merkez ülkeler çevre ülkelerin gelişmelerinin yolunu DTÖ kapsamındaki korumacılık politikası araçları yardımıyla kendi çıkarları doğrultusunda engellemeye çalışmaktadır. Bu da uluslararası alanda eşitsiz gelişmeye yol açmaktadır. Merkez ülkelerin korumacılık politikalarını aktif bir şekilde kullanmaları sanayilerinin gelişmesine ve sonuçta dünya ticaretinden aldıkları payın artmasına imkan sağlamaktadır. Merkez ülkeler korumacılık politikaları aracıllı̆ıyla yönettikleri kalkınma süreçlerini tamamlayarak, bu süreçte elde etmiş oldukları üstünlükleri serbest piyasa dayatması altında korumaya çalışmaktadır. 


\section{Kaynakça}

Amin, S. (1973). Unequal Development: An Essay on the Social Formations of Peripheral Capitalism, (Çev.) Pearce, B., England, The Harvester Press.

Aslan, A. (2003). "Küreselleşme Bağlamında Kalkınma Politikalarına Sosyolojik Bir Bakış", Anemon Muş Alparslan Üniversitesi Sosyal Bilimler Dergisi, C. 1, S. 1, ss. 173-189.

Ateş, D. (2016). Uluslararası Örgütler Devletlerin Örgütlenme Mantığı, 3. Baskı, Bursa: Dora Yayıncilık.

Baran, P. A. (1957). The Political Economy of Growth, Pelican Books, Monthly Review Press.

Başkaya, F. (2004). Kalkınma iktisadının Yükselişi ve Düşüşü, 4. Baskı, Ankara: Maki Basın Yayın.

Başkol, M. O. (2010). "Ithalatta Haksız Rekabetin Önlenmesinde Anti-Damping Soruşturmalarının Etkinliği", Ekonomi Bilimleri Dergisi, C. 2, S. 1, ss. 107-114.

Chang, H. \& Grabel, I. (2005). Kalkınma Yeniden, (Çev.) Özçelik, E., Ankara: İmge Kitabevi.

Chilcote, R. H. (1974). "Dependency: A Critical Synthesis of the Literature", Latin American Perspectives, Vol. 1 (1), pp. 4-29.

Dobb, M. (1981). Kapitalizm Sosyalizm Azgelişmiş Ülkeler ve Iktisadi Kalkınma, (Çev.) Selik, M. Ankara: Ankara Üniversitesi Siyasal Bilgiler Fakültesi Yayınları, Yayın No: 464.

Dünya Ticaret Örgütü Anti-Damping Anlaşması, https://www.wto.org/english/ docs_e/legal_e/19-adp_01_e.htm (01.01.2018).

Ercan, F. (2003). Modernizm, Kapitalizm ve Azgelişmişlik, 3. Baskı, Ankara: Bağlam Yayınları.

Erdoğan, i. (2000). Kapitalizm, Kalkınma, Postmodernizm ve Iletişim Sömürünün Paketlenişi, Ankara: Pozitif Matbaacllık.

Frank, A. G. (1967). Capitalism and Underdevelopment in Latin America, New York: Monthly Review Press.

http://www.trademap.org/tradestat/index.aspx (01.11.2017).

https://www.wto.org/english/tratop_e/dispu_e/dispu_status_e.htm (01.11.2017).

İstanbul Ticaret Odası. (2011). Sorularla Dış Ticarette Korunma Önlemleri, Haksız Rekabetin Önlenmesi ve Gözetim Uygulaması, Yayın No: 2010-89, İstanbul.

Kalaycıoğlu, S. (1991). Dış Ticarette Korumacılık ve Liberasyon, İstanbul: Beta Basım Yayım Dağıtım. 
Kazgan, G. (2015). Küreselleşme ve Ulus Devlet Yeni Ekonomik Düzen, 6. Baskı, İstanbul: İstanbul Bilgi Üniversitesi Yayınları.

Mangır, F. \& Acet, H. (2014). "Serbest Ticaret ve Korumacılık, Avrupa Birliği'nde Malların Serbest Dolaşımı ve Türkiye'nin Uyumu", Selçuk Üniversitesi Sosyal Bilimler Enstitüsü Dergisi, Dr. Mehmet Yıldız Özel Sayısı.

Öz, S. (2009). "Kriz ve Korumacılık: Tarih Tekerrür Edecek mi?”, TüsiAD-Koç Üniversitesi Ekonomik Araştırma Forumu Çalışma Raporu Serisi, Çalışma Raporu 0904.

Öztürk, N. (2014). Maliye Politikası, Ekin Basım Yayın, 2. Baskı, Bursa.

Palma, J. G. (2008). "Dependency", The New Palgrave Dictionary of Economics, (Ed.) Durlauf, S. N. \& Blume, L. E., Palgrave Macmillan.

Sanchez, O. (2003). "The Rise and Fall of the Dependency Movement: Does It Inform Underdevelopment Today?”, E.I.A.L., Vol. 14 (2), pp. 31-50.

Schumacher, R. (2012). "Adam Smith's theory of absolute advantage and the use of doxography in the history of economics", Erasmus Journal for Philosophy and Economics, Vol. 5 (2).

Selen, U. \& Gümüş, S. (2011). "Piyasa Ekonomisinde Koruyucu İktisat Politikalarının ve Ticaret Politikası Önlemlerinin Analizi", Ekonomi Bilimleri Dergisi, C. 3, S. 2, ss. 213-228.

Selen, U. (2008). "1980 Sonrası Neo-Liberal Politika Uygulamalarının Eleştirisi”, iktisat Dergisi, Ağustos, ss. 99-114.

Seyidoğlu, H. (2003). Uluslararası Iktisat, İstanbul: Güzem Can Yayınları.

Solmaz, E. (2008). "iktisadi Kalkınma Kuramlarının Yoksulluk Konusuna Yaklaşımlarına Eleştirel Bir Bakış", Mevzuat Dergisi, C.11, S. 132.

Şenses, F. (2004). "Neoliberal Küreselleşme Kalkınma İçin Bir Fırsat mı, Engel mi?”, Economic Research Center Working Paper in Economic 04/09.

Tokatlıŏlu, M. \& Selen, U. (2017). Maliye Politikası, Bursa: Ekin Basın Yayın Dağıtım.

Tüylüoğlu, Ş. (2004). "Küreselleşme Sürecinde Kalkınma Politikaları ve Devletin Zayıflayan Rolü", Süleyman Demirel Üniversitesi iktisadi ve idari Bilimler Fakültesi Dergisi, C. 9, S. 1, ss. 257-280.

Wallerstein, I. (2004). World System Analysis: An Introduction, Durham: Duke University Press.

Woods, N. \& Narlikar, A. (2001). "Governance and the limits of accountability: the WTO, the IMF, and the World Bank", Blackwell Publishers, Oxford. 